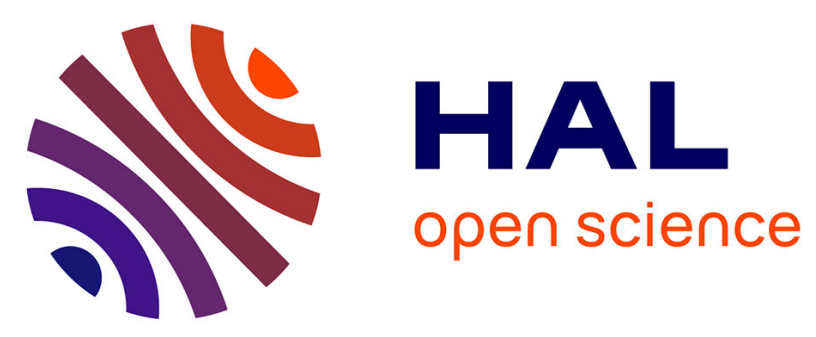

\title{
The Legal Landscape for Advanced Therapies: Material and Institutional Implementation of European Union Rules in France and the United Kingdom
} Aurélie Mahalatchimy, Emmanuelle Rial-Sebbag, Virginie Tournay, Alex Faulkner

\section{To cite this version:}

Aurélie Mahalatchimy, Emmanuelle Rial-Sebbag, Virginie Tournay, Alex Faulkner. The Legal Landscape for Advanced Therapies: Material and Institutional Implementation of European Union Rules in France and the United Kingdom. Journal of Law and Society, 2012, 39 (1), pp.131-149. 10.1111/j.1467-6478.2012.00574.x/full . hal-01560611v2

HAL Id: hal-01560611

https: / hal-sciencespo.archives-ouvertes.fr/hal-01560611v2

Submitted on 7 Nov 2017

HAL is a multi-disciplinary open access archive for the deposit and dissemination of scientific research documents, whether they are published or not. The documents may come from teaching and research institutions in France or abroad, or from public or private research centers.
L'archive ouverte pluridisciplinaire HAL, est destinée au dépôt et à la diffusion de documents scientifiques de niveau recherche, publiés ou non, émanant des établissements d'enseignement et de recherche français ou étrangers, des laboratoires publics ou privés. 


\section{The Legal Landscape for Advanced Therapies: Material and Institutional Implementation of European Union Rules in France and the United Kingdom}

Aurélie MAHALATCHIMY, Emmanuelle RIALSEBBAG, Virginie TOURNAY and Alex FAULKNER 


\section{INTRODUCTION}

'Human materials' are increasingly being used in developing medical products under the impetus of the life sciences. Many of these new products are seen as part of the global trend toward 'regenerative medicine', a new paradigm for medicine itself. Such developments attract the attention of law making and regulation, with the goals of protecting and improving public health, ensuring safety, and advancing scientific and industrial ambitions. These developments are producing significant shifts in the relationships between the human and material worlds, bringing them closer together and complicating their distinction. Such shifts have been theorized by sociologists using terms such as 'biomedicalization'. 'Human tissues, cells, and genes have become the object of regulation worldwide, including new laws in the European Union, which has caused 'a major reshaping of the regulatory landscape of the life-sciences in Member States'. ${ }^{2}$ As will be seen in this discussion, the new EU law raises a number of issues that are important to analysis from the perspectives of socio-legal studies and science and technology studies. Conspicuous amongst these is the issue of how legal concepts and regulatory institutions can be 'matched' to the scientific, technological, and industrial categories that emerge in the development and testing of complex new medical materials, and how these vary in the framings of different, bounded legal regimes such as national political cultures, building on existing regimes. ${ }^{3}$ Scientists and governments are faced with products derived from living matter, which are, by definition, much more difficult to stabilize than manufactured products using and processing inert materials.

As will be shown below, a new EU 'advanced therapy' regulation defines, more or less, what henceforth does and does not constitute a human materials-derived medical product 'within the law', and it also leaves open some key questions about how certain classes of medical artefact, produced under certain circumstances, might be regulated when they fall outside the EU-wide regime that the new regulation established. Crucially, for example, this raises issues of what types of social actors in what types of institutions may participate in the EU regime of regenerative medicine, ${ }^{4}$ either as

1 A.E. Clarke et al., 'Biomedicalization: Technoscientific transformations of health, illness, and US biomedicine' (2003) 68 Am. Sociological Rev. 161-94.

2 M. Favale and A. Plomer, 'Fundamental disjunctions in the EU legal order on human tissue, cells and advanced regenerative therapies' (2009) 16 Maastricht J. of European and Comparative Law 89-111.

3 V. Tournay (ed.), La gouvernance des innovations médicales (2007).

4 We use the term 'regenerative medicine' to refer broadly to the field under discussion even though it is not equivalent to 'advanced therapy medicinal products'. We do so because it has become a widely used term, especially amongst participating scientists and industry, and is also known to the public, rather than because it has a legal definition. As used here, it may refer to a range of therapeutic applications such as prevention and repair as well as strictly 'regeneration'. 
producers or users/consumers. The discussion below will show how the new legal regimes grapple with trying to define delicate distinctions between, for example, what is and is not a 'hospital', what is and is not an 'industrial process' using human materials, and how the borderline is drawn between commodification and non-commodification or commercialization. ${ }^{5}$ The new regulation thus enters into the heart of the professional working routines and standards involved in the biotherapeutic manufacturing process. In order to highlight these questions, therefore, we focus in particular in this discussion on the borderline between what is and what is not included in the new EU human tissues and cells and advanced therapy regimes, on some of the most relevant rules regarding clinical trials for new medical entities, and how these matters are being approached institutionally and in terms of the legal conceptualization of human materials, in two contrasting EU countries, namely, France and the United Kingdom.

Perhaps the most conspicuous feature of the legal landscape for the scientific research, materials, and products of regenerative medicine, is its sheer complexity. Much of this complexity is illustrated in the descriptions of relevant laws provided in the body of this paper. To some extent this complexity is ironic, given the aim of the European Commission to provide 'legal clarity' and harmonization within the European area through the development of a new legal regime. The question of the extent to which this complexity and instability is, as it were, the 'natural' reflection of the biologies and ever-evolving living technologies involved, or the extent to which it is more the result of interacting regulatory, social and ethical, and institutional forces, is a key one that the article addresses. Regardless, different countries are tackling the regulation of these materials and associated sciences and technologies in widely different ways, resulting in a segmented marketplace of different regulatory regimes involved in constituting the emerging worlds of the new regenerative medicine paradigm.

The article now turns to consider the recent developments in EU law relating to regenerative medicine in the form of its 'starting materials' of tissues and cells, and the new category of 'advanced therapy' which is the outcome of several years' protracted negotiation between stakeholders in this field.

5 In this paper, we consider that the English 'non-commodification' corresponds to the French principle of 'non-patrimonialité' of the human body and its elements, which means that the human body and its elements cannot be the object of a financial agreement. 


\section{REGENERATIVE TECHNOLOGIES AND MEDICAL MATERIALS REGULATED BY EU LAW: LEGAL REGIMES ENFORCEABLE IN FRANCE AND THE UNITED KINGDOM}

Human cells and tissues have been identified as a distinct category of medical material for legislation in the EU, and an entirely new category of product has also been devised by regulators, namely, 'Advanced Therapy Medicinal Products' (ATMP). This 'advanced therapy' designation does not exist as a legal categorization elsewhere in the world. Advanced Therapy Medicinal Products have been defined in the EU as medicinal products based on genes, cells or tissues. Gene therapy, ${ }^{6}$ for example, targeted at cancer cells or aimed to replace defective genes in diseases with genetic causation such as cystic fibrosis, and cell therapy, ${ }^{7}$ for example, a patient's cartilage cells extracted, multiplied, and re-implanted, have been regulated as medicinal products under the EU general legal framework since 2003. ${ }^{8}$ But tissue-engineered products ${ }^{9}$ (TEPs), for example, 'living skin' including a layer of manufactured biomaterial, lay outside any EU legislation.

In Europe, products utilizing human tissues/cells may be regulated either by EU law or by national laws, depending on the determined material and legal character of the 'product' and/or the institutional and work-routine features of the process of preparing it. A comparative approach can shed

6 Gene therapy medicinal products means:

a biological medicinal product which has the following characteristics: it contains an active substance which contains or consists of a recombinant nucleic acid used in or administered to human beings with a view of regulating, repairing, replacing adding or deleting a genetic sequence; its therapeutic, prophylactic or diagnostic effect relates directly to the recombinant nucleic acid sequence it contains, or the product of genetic expression of this sequence. Gene therapy medicinal products shall not include vaccines against infectious diseases.

Annex, Part IV, 2.1 of Directive 2009/120/EC.

7 A somatic cell therapy medicinal product means a biological medicinal product which:

contains or consists of cells or tissues that have been subject to substantial manipulation so that biological characteristics, physiological functions or structural properties relevant for the intended clinical use have been altered, or of cells or tissues that are not intended to be used for the same essential function(s) in the recipient and the donor; [and] is presented as having properties for, or is used in or administered to human beings with a view to treating, preventing or diagnosing a disease through the pharmacological, immunological or metabolic action of its cells or tissues.

Annex, Part IV, 2.2 of Directive 2009/120/EC.

8 Directive 2003/63/EC of 25 June 2003, amending Directive 2001/83/EC of the European Parliament and of the Council on the Community code relating to medicinal products for human use, OJ L159/46, 27.06.2003.

9 A tissue engineered product contains or consists of engineered cells or tissues (of human or animal origin or both, viable or non-viable), and is presented as having properties for human beings to regenerate, repair or replace a human tissue: Regulation (EC) No. 1394/2007 on ATMP, Article 2.1(b). 
light on the complexity and flexibility of different national regimes within the over-arching EU risk-based regime. ${ }^{10}$ Thus, we will analyse and compare how France and the United Kingdom, both countries with relatively high levels of activity in the regenerative medicine sector, regulate medical materials and advanced therapy medicinal products which do and do not fall under the scope of the new EU laws applicable to regenerative products using human materials.

The structure of the discussion is as follows. First, we explain the legal frame for tissues and cells used in therapy and manufactured as products regulated by EU law, as it is enforceable in every EU member state, noting differences in implementation between France and the United Kingdom. Secondly, analysis will be presented of how each country regulates products which remain not covered by EU law. This raises the issue of the 'industrial process' of routine production of therapies, by which the new regulation attempts to distinguish commercial enterprise from 'hospital'-based preparation of therapies for single patients on a one-off basis, a key point of negotiation and conflict during the political discussion of the new products Regulation.

\section{THE LEGAL FRAME FOR TISSUES AND CELLS USED FOR HUMAN APPLICATIONS AND PREPARED OR MANUFACTURED FOR USE IN OR AS PRODUCTS}

Three main fields particularly relevant for companies and other establishments developing regenerative medicine products using tissues and cells have been regulated at EU level: (i) the use of human tissues and cells for human application; (ii) clinical trials; and (iii) marketing authorization and follow-up of regenerative/advanced therapy medicinal products (ATMPs). Below we describe each of these in turn. These sets of laws and regulations are highly complex, and we therefore of necessity summarize the main legal measures and institutional aspects as they refer to the biological materials and products.

\section{The EU regulation of tissues and cells as medical materials}

Tissues and cells, when considered as medical materials, have to rely on two pieces of legislation divided according to the chain from procurement to the distribution of the final medicinal products. On the one hand, three EU Directives have been developed to regulate the procurement and use of human tissues and cells for human application. Directive 2004/23/EC of

10 See A.-M. Farrell, 'The politics of risk and EU governance of human material' (2009) 16 Maastricht J. of European and Comparative Law 41-64. 
31 March 2004, often called the "mother directive" (also known in shorthand as the 'Tissues and Cells' Directive, or sometimes, and more informatively, the 'tissue banking' Directive), provides the framework legislation, ${ }^{11}$ and two supplementary technical Directives provide detailed requirements. ${ }^{12}$ These Directives establish quality and safety standards. On the other hand, where a product enters in the scope of the Regulation on ATMP,${ }^{13}$ the Tissues and Cells Directive will only apply for the donation, procurement, and testing phases of the medical materials. The later steps (processing, storage, and distribution) have to comply with the Regulation on ATMP $^{14}$ which concerns medicinal products (see below). This means that two complementary sets of rules have to be respected. Interestingly, one main institution, AFSSAPS-French Agency for the Safety of Health Products, will control the enforcement of these rules in France although an opinion may be required from the Biomedecine Agency, ${ }^{15}$ whereas, in the United Kingdom, at least three agencies are in place to cover the whole chain of human materials activity: the Human Tissue Authority (HTA) for the regulation of tissues and cells other than gametes and embryos for human application, the Human Fertilisation and Embryology Authority (HFEA) ${ }^{16}$ for the regulation of gametes and embryos for human application, and the Medicinal and Healthcare products Regulatory Authority (MHRA) for medicinal products based on human body elements.

The directives on tissues and cells have been transposed into British ${ }^{17}$ and French $^{18}$ laws. In France, AFSSAPS ${ }^{19}$ is in charge of the technical imple-

11 Directive 2004/23/EC of the European Parliament and of the Council of 31 March 2004 on setting standards of quality and safety for the donation, procurement, testing, processing, preservation, storage and distribution of human tissues and cells, OJ L102/48, 07.04.2004.

12 Directive 2006/17/EC of 8 February 2006 implementing Directive 2004/23/EC as regards certain technical requirements for the donation, procurement and testing of human tissues and cells, OJ L38/40, 09.02.2006, and Directive 2006/86/EC of 24 October 2006, implementing Directive 2004/23/EC as regards traceability requirements, notification of serious adverse reactions and events, and certain technical requirements for the coding, processing, preservation, storage, and distribution of human tissues and cells, OJ L294/32, 25.10.2006.

13 ATMP Regulation, op. cit., n. 9, Preamble (6).

14 id., Article 3.

15 The French Biomedecine Agency was set up by the 2004 Bioethics Law. It is the reference authority for medical, scientific, and ethical aspects, notably those related to procurement and transplant of organs, tissues, and cells: <http://www.agencebiomedecine.fr $/>$.

16 HFEA, at $<$ http://www.hfea.gov.uk/>.

17 Human Tissue (Quality and Safety for Human Application) Regulations 2007: these Regulations complete the Human Tissue Act 2004 which covers England, Wales, and Northern Ireland (Scotland has separate provision).

18 In France, many legal texts implement those directives: notably, Law n2011-814 of 7 July 2011 on bioethics, French OJ n157, 08.07.2011, 11826, text n1.

19 AFSSAPS, at <http://www.afssaps.fr/>. 
mentation of the regulation. French law does not only provide stringent safety requirements for human tissues and cells, it also protects them through fundamental rights and, notably, the principle of respect for human dignity as elements of the human body through the integration of measures protective of the human body within the civil code regarding the respect due to the person.

In the United Kingdom, the HTA ${ }^{20}$ detailed in specific guidance the standards required under the Human Tissue Regulations. ${ }^{21}$ The overwhelming weight of provision in the United Kingdom's Human Tissue Act is devoted to elucidating the principles of informed consent by patients.

However, the abolition of the HTA and the HFEA is being discussed in the United Kingdom (spring 2011). A previous review in December 2006 proposed to merge the HTA and the HFEA into a single Regulatory Authority for Tissue and Embryos ${ }^{22}$ and the positioning of these bodies is again the subject of government attention. This question was debated on 1 February 2011 where a spokesman for the Department of Health stated that his department was 'planning to undertake a public consultation exercise ... about where HFEA and HTA functions are best transferred' ${ }^{23}$ Nevertheless, the existence of two agencies presents the advantage of distinguishing clearly the two sets of rules enforceable for human tissues and cells either as raw materials or as medicinal products once transformed by a biomanufacturing process. But, at the same time, it could be seen as a more complex framework for researchers and manufacturers who might have difficulties understanding the remit of each agency. Equally, in France, it may be considered inconsistent, ambiguous, and potentially a conflict of interest to highlight the significance of the implementation of fundamental rights to human body elements while the same agency also controls both the procurement of human body elements and the development of health products based on them. However, the Biomedecine Agency appears to have a safeguard for ethical matters, in particular through its advisory council, even though this is not an ethics committee. Thus, we can see that, whereas the weight of the implementation of the law in France is on non-commodification, in the United Kingdom the major focus is more on the institutionalization of individual consent procedures for allowing but controlling citizens' and patients' rights over use of body materials.

20 HTA, at $<$ http://www.hta.gov.uk/>.

21 HTA, Guide to Quality and Safety Assurance of Human Tissues and Cells for Patients Treatments (2010); HTA Directions 003/2010 relating to licences granted under the Human Tissue (Quality and Safety for Human Application) Regulations 2007.

22 Department of Health, Review of the Human Fertilisation and Embryology Act: Proposals for revised legislation (including establishment of the Regulatory Authority for Tissue and Embryos) (2006; Cm. 6989).

23 Earl Howe, 724 H.L. Debs col. GC 343 (1 February 2011). 


\section{EU regulation of clinical trials}

Regenerative or advanced therapy products have been deemed to be highrisk products which will therefore require clinical trials to place them in the European marketplace. Directive 2001/20/EC on clinical trials for medicinal products for human use $^{24}$ and Directive 2005/28/EC for good clinical practice $^{25}$ as regards investigational medicinal products, ${ }^{26}$ and authorization of their manufacture or importation, apply to regenerative medicine products. The Regulation on ATMP, detailed below, extended application of the therapy-specific rules to tissue-engineered products $^{27}$ and to the adoption of guidelines specific to ATMPs. ${ }^{28}$

Two main specific rules apply to clinical trials involving an advanced therapy product. First, the usual 60-day decision period following a valid clinical trial application can been extended to 90 days for products based on human body elements, and it may be doubled where the consultation of a group or a committee is deemed required by the member state concerned. ${ }^{29}$ Secondly, while the non-opposition of the authority is usually sufficient to start a clinical trial, an explicit written authorization is required for trials involving ATMPs or any medicinal product containing genetically modified organisms, indicating the high degree of risk perceived. ${ }^{30}$ Apart from EU clinical trials law, France and the United Kingdom each have specific measures regarding the clinical trials of products based on human body elements, which we note below.

In France, EU law on clinical trials applies to medicinal products derived from gene therapy ${ }^{31}$ and from cell therapy which are still considered to be medicinal products in French law. Thus it applies to gene therapy, that is, pharmaceutical products and preparations ${ }^{32}$ derived from gene therapy, and

24 OJ L121/34, 01.05.2001.

25 OJ L91/13, 09.04.2005.

26 Directive 2001/20/EC, Article 2(d), defines an 'investigational medicinal product' as:

a pharmaceutical form of an active substance or placebo being tested or used as a reference in a clinical trial, including products already with a marketing authorization but used or assembled (formulated or packaged) in a way different from the authorized form, or when used for an unauthorized indication, or when used to gain further information about the authorized form.

27 ATMP Regulation, op. cit., n. 9, Article 4(1).

28 European Commission, Detailed guidelines on good clinical practice specific to advanced therapy medicinal products, 3 December 2009, ENTR/F/2/SF/dn D(2009) 35810.

29 Directive, op. cit., n. 26, Articles 6(7) and 9(4).

30 id., Article 9(6).

31 Article L5121-8 of the French Public Health Code. They are prepared in advance and according to an industrial process. Thus, they are submitted to EU legislation on ATMP and to a centralized marketing authorization.

32 Article L5121-1-12 ${ }^{\circ}$ of the French Public Health Code. They are prepared in advance and to one or several patients on medical prescription. As there is no industrial 
to cell therapy, ${ }^{33}$ that is, pharmaceutical products derived from human and xenogeneic (animal materials-based) cell therapy ${ }^{34}$ and preparations derived from xenogeneic cell therapy. ${ }^{35}$ When the research involves genetically modified organisms, the highest possible level of authorization is invoked, so the clinical trial application dossier must comprise the classification of the organism by the Haut Conseil des Biotechnologies (High Council of Biotechnologies $-\mathrm{HCB})^{36}$ and the consent of the Ministry in charge of research. ${ }^{37}$ However, importantly, preparations derived from human cell therapy are never considered as medicinal products in French law. Consequently, they fall under the legal regulations governing human cells and tissues ${ }^{38}$ discussed above, including for clinical trials, ${ }^{39}$ as distinct from the ATMP product Regulation discussed below. The regime for tissue engineering is identical as for cell therapy.

In the United Kingdom, a specific national 'Gene Therapy Advisory Committee' (GTAC) has responsibility for the ethical review of research study involving not only gene therapy, but also embryonic stem-cell therapy, cell therapies derived from stem-cell lines, and the therapeutic use of genetically modified stem cells or therapeutic xenotransplanation. Interestingly, from 1 May 2008, the GTAC can transfer applications to other (locally-based) Research Ethics Committees if a gene therapy proposal is deemed to be 'low genetic risk'. ${ }^{40}$ The notion of 'low genetic risk' can be regarded as a technical tool, set up by the GTAC itself. In spite of a 'decision tree $^{41}$ indicating the regulatory routing of products, this notion is not clearly defined. In France, such a concept does not exist, but neither is the range of applications covered by the HCB clearly defined. Although the HCB to date has given opinions on gene therapy only, its mission also covers 'other biotechnologies'. ${ }^{42}$ Thus, in legal terms, it seems there is a non-defined

process, they are not submitted to the EU legislation on ATMP. The marketing authorization is delivered by AFSSAPS for a specific therapeutic use.

33 Article L1243-1 of the French Public Health Code.

34 Art. L5121-8, op. cit., n. 31.

35 Article L5121-1-13 ${ }^{\circ}$ of the French Public Health Code.

36 The HCB replaces the Commission de Génie Génétique (Genetic Engineering Committee) and the Commission d'étude de la dissémination des produits issus de génie biomoléculaire (Committee for studying the dissemination of products derived from biomolecular engineering).

37 See, notably, Articles R1125-1, R1125-3, R1125-8, R1125-10, and R1125-11 of the French Public Health Code.

38 Article L1243-1 of the French Public Health Code.

39 Article R1243-1 of the French Public Health Code, and Decree 2008-968 (Décret $\mathrm{n}^{\mathrm{o}}$ 2008-968 du 16 septembre 2008 (autorisations d'activités et de produits)).

40 Amendment of regulation 15 of the Clinical Trials Regulations, 3(c)(4B) of the Medicines for Human Use (Clinical Trials) and Blood Safety and Quality (Amendment) Regulations 2008 S.I. 2008/941.

41 Department of Health, GTAC, Agreed Decision tree, at: <http://www.dh.gov.uk/prod consum_dh/groups/dh_digitalassets/@dh/@en/documents/digitalasset/dh_087984.pdf >

42 Article $\bar{L} 531-3$ of the French Environment Code. 
stratification of risks for clinical trials of such health products, associated with institutional flexibility. In both cases, it appears therefore that there is significant scope for discretionary decision making, under conditions of uncertainty, on a case-by-case basis by constituted groups of experts, in spite of, or at least alongside, the complex decision trees and specific nationallevel regulatory institutions that have been developed.

It is interesting to note that in both France and the United Kingdom, there is a specific committee in charge of the assessment of risks for particular gene therapy. The remit regarding the range of types of product of the HCB in France is wider than that of the GTAC in the United Kingdom, showing that there can be flexibility built in to the scope of apparently specificallydesigned regulatory bodies, partly for the pragmatic reason of the limited available expertise and its organization, and pointing to the unstable and open-ended nature of the regulated objects.

\section{The EU regulation for marketing authorization and follow-up of regenerative products as advanced therapy medicinal products}

Commercial establishments brought under regulation of EU competition laws are brought into an EU 'harmonized' regime. On 13 November 2007, the EU adopted a lex specialis ${ }^{43}$ addressing what were then legally termed advanced therapies, including TEPs, within a claimed single coherent framework in order to bridge the pre-existing regulatory gap for TEPs: Regulation (EC) No. 1394/2007 ('the Regulation on ATMP'). ${ }^{44}$ This includes a provision for a central and unique marketing authorization at the European Medicines Agency (EMA) level where a new Committee for Advanced Therapy (CAT) has been created, ${ }^{45}$ meaning that once authorized, products may be made available throughout the EU member states without recourse to separate national marketing authorizations.

Since the adoption of the Regulation on ATMP, four types of biological medicinal products based on genes, cells, and tissues are regulated at EU level: gene therapy medicinal products (GTMP), somatic cell therapy medicinal products (CTMP), tissue-engineered products (TEPs), and combined $\mathrm{ATMP}^{46}$ which associates a medical device with an advanced therapy. The EMA can provide an informal scientific recommendation on the

43 The Latin 'lex specialis' notion comes from the legal maxim 'lex specialis derogat legi generali'. A 'lex specialis' is a 'law' which governs a specific subject matter. The legal maxim means that a law governing a specific subject matter overrides a law that only governs general matters. For our subject, Regulation (EC) No. 1394/2007 overrides the general EU pharmaceutical legislation.

44 OJ L324/121, 10.12.2007.

45 The Marketing Authorization is granted by the European Commission after consulting the new CAT and the Committee for Medicinal Products for Human Use within the EMA.

46 ATMP Regulation, op. cit., n. 9, Article 2.1(d). 
classification of products. ${ }^{47}$ The Regulation applies to products which correspond to the EU legal definitions and 'which are intended to be placed on the market in Member States and are either prepared industrially or manufactured by a method involving an industrial process ${ }^{48}$ (our emphasis). Unsurprisingly perhaps, there are difficulties in distinguishing which products are covered and which are not. The European Commission has tried to clarify the 'industrial process':

This should cover, inter alia: Any 'mass production' of advanced therapy products for allogeneic use (batch production, 'off the shelf' products etc.); any advanced therapy product for autologous use (i.e. using cells/tissues from a single patient and re-implanting after manipulation into same patient) which, although being patient-specific by definition, is manufactured in accordance with a standardised and industrial process. ${ }^{49}$

This classificatory distinction is crucial to defining the status and responsibilities of producers of regenerative products, whether in hospitals or in the commercial sector, and was the subject of major debate amongst interested stakeholders in the negotiation of the Regulation. ${ }^{50}$ The Regulation also strengthens 'post-authorization' requirements ${ }^{51}$ and provides a reinforced traceability. ${ }^{5}$

The ATMP Regulation is directly enforceable in British and French laws, which have been modified to comply with EU law through the Medicines for Human Use (Advanced Therapy Medicinal Products and Miscellaneous Amendments) Regulations 2010 for the United Kingdom, and a new law adapting French law to the EU law adopted on 22 March $2011^{53}$ in which Article 8 is devoted to ATMP for France.

Having described and discussed the regulation of human tissues and cells as medical materials, clinical trial aspects, and products as advanced therapies, we turn, secondly, to examine the question of body elements and products which may remain not covered by these EU-level laws. As noted in our introduction, this highlights further the question of under what circumstances is a product to be regarded as prepared by an 'industrial process,' which has direct consequences for the regimes that will apply and the commercial and safety interests of producers and consumers - companies, hospitals, physicians, and patients.

47 id., Article 17.

48 id., Preamble (6).

49 Commission staff working document.

50 See A. Faulkner, Medical Technology into Healthcare and Society (2009) ch. 8.

51 ATMP Regulation, op. cit., n. 9, Article 14.

52 id., Article 15.

53 Law 2011-302 of 22 March 2011, J. Officiel De La République Française (23 mars 2011) texte $n^{\circ} 6$. 


\section{REGENERATIVE TECHNOLOGIES NOT REGULATED BY EU LAW AS ADVANCED THERAPY MEDICINAL PRODUCTS: THE INFLUENCE OF EU LAW IN FRANCE AND THE UNITED KINGDOM}

\section{Tissues and cells for graft or transplant}

In France and the United Kingdom, tissues and cells used for graft or transplant are not classified as medicinal products. They are regulated in order to comply with the EU Directives on tissues and cells outlined above.

In France, the regulation of human tissues and cells for therapeutic purposes is the same as for 'preparations' of human cell therapy. Producers must obtain an authorization from AFSSAPS, after assessment of their processes for preparation and preservation, as well as their therapeutic indications, and after advice and consent from the Biomedecine Agency. ${ }^{54}$ Various specific decrees have been drawn up such as Decree no. 2008-968 ${ }^{55}$ which makes a distinction between institution authorization for preparation, preservation, distribution and transfer of tissues, their by-products, cells and preparations derived from cell therapy and authorization of the processes for such materials. ${ }^{56}$

In the United Kingdom, on the other hand, an establishment which wants to store human tissues and cells for human application needs a licence. Regarding the activities of procurement, testing of donor samples, processing, import and export, and distribution of tissues and cells for human application, either a licence or a third-party agreement with a licensed establishment is required. Such a licence is currently provided by the HTA in accordance with the Human Tissue (Quality and Safety for Human Application) Regulations 2007 implementing the EU Directives on tissues and cells.

\section{The 'hospital exemption'}

As noted above, the ATMP Regulation provides a 'hospital exemption'; ATMPs which are:

prepared on a non-routine basis according to specific quality standards, and used within the same Member State in a hospital under the exclusive responsibility of a medical practitioner, in order to comply with an individual medical prescription for a custom-made product for an individual patien ${ }^{57}$

are not covered. Thus, manufacture under the hospital exemption must be authorized by member states. In French law, ATMPs under the hospital

54 Article L1243-5 of the French Public Health Code.

55 Decree 2008-968, op. cit., n. 39.

56 Article R1243-1, op. cit., n. 39, and id.

57 ATMP Regulation, op. cit., n. 9, Preamble (6) and Article 28(2). 
exemption were regulated as 'preparations'. However, the new law adopted to modify French law to comply with the ATMP Regulation provides that only establishments or entities authorized by AFSSAPS, following an opinion given by the Biomedecine Agency, and pharmaceutical establishments, can prepare, preserve, distribute, and transfer ATMPs under the hospital exemption, and in accordance with good practices to be defined by the French agencies. ${ }^{58}$ A specific Decree will be adopted to define the categories of establishments and modalities which can be authorized. In the United Kingdom, the MHRA has provided guidance on what constitutes non-routine preparation of a product. ${ }^{59}$ Two main questions are asked: first, is it the same product, repeatedly under consideration? Second, what are the scale and frequency of the preparation of the product? The MHRA has also developed guidance on the United Kingdom's arrangements under the hospital exemption scheme. ${ }^{60}$ This sets up specific standards, including on good manufacturing practice and quality, pharmaco-vigilance, traceability, sanctions and penalties, and requirements outside the Regulation such as labelling, package leaflet requirements, and advertising. Such guidance does not provide new legislative requirements under the hospital exemption, stipulating that NHS trusts may deal with clinical ethical issues and the GTAC could provide ethical advice.

Again, in both France and the United Kingdom, we can see the way in which the attempt to regulate therapies not intended for commercial marketing grapples with the 'boundary work' of adapting existing regimes to new laws, and the potential for uncertainty in applying classifications that make commercially consequential sectoral (hospital, company) distinctions between the actors in the regenerative therapy field.

\section{Others categories in national laws}

Separate from grafting and transplant and hospital exemption provisions, France and the United Kingdom have a range of further provisions designed to cover particular types of product or methods of preparation or production. Space prohibits a full discussion of these, but we note the following key points. First, in French law, gene therapy and xenogeneic cell and tissue engineering preparations are considered as medicinal products although they are not manufactured at an industrial scale. Establishments and processes have to be authorized by AFSSAPS. Preparations from human tissue engineering and human cell therapy fall under the regulations governing human cells and tissues rather than medicinal products, a fine distinction reflecting the particular history and basis of French law. Second, in British law, two other

58 See, notably, articles L4211-9, L5124-1, L5121-5 of the French Public Health Code.

59 MHRA, Annex B, Guidance on 'non-routine'.

60 MHRA, ATMPs Guidance. 
regimes can be applied to medicinal products based on genes, cells or tissues, the pre-existing United Kingdom 'Specials' exemption, or the Medicines Act exemptions. These exemptions are complex and are under development at the time of writing; at first sight, they appear difficult to distinguish from the ATMP hospital exemption. The 'specials' scheme provides that to 'fulfil special needs' the provisions of the medicines Directive need not be met to respond to 'a bona fide unsolicited order ... for use by an individual patient'. For such products only a manufacturer's licence is required. Further, although in principle a product licence is required to procure, sell, supply or export a medicinal product, along with a manufacturer's licence, ${ }^{61}$ exemptions are provided for doctors and pharmacists by the Medicines Act 1968. Such exemptions would apply to ATMPs as to other medicinal products.

Thus it appears that the regulatory work of providing for exemptions for the production and use of regenerative therapy products in the EU regime is being addressed strongly but differently in the United Kingdom and France as they wrestle with existing regimes. The different ethically-motivated emphasis between the two states reappears here, with France again relying more on a standpoint on non-commodification (shown by the refusal to qualify human cell or tissues based preparations as 'products') compared to the United Kingdom's greater concern with product licensing issues.

\section{DISCUSSION}

Processes of classification of medical products can be seen as part of society's regulatory ordering of innovating technological sectors or zones. ${ }^{62}$ They demonstrate change of constitutional significance in the relations between living entities, technologies, and states. ${ }^{63}$ Society's regulatory classifications of technology, as in other arenas, have important consequences for how risks and benefits are perceived, ${ }^{64}$ constructed, and managed; what regimes of evidence are brought into play; what private or public resources are deployed; and what characteristics shape publics' approval or concerns about the uses of the technology. The structuring work of classification is particularly striking in the socio-medical and industrial worlds of medicine and healthcare. ${ }^{65}$

61 Section 7(2) of the Medicines Act 1968.

62 A. Faulkner, 'Regulatory policy as innovation: constructing rules of engagement of a technological zone for tissue engineering in the European Union' (2009) 38 Research Policy 637-46.

63 S. Jasanoff, Designs on Nature: Science and Democracy in Europe and the United States (2005).

64 For more detail, see M.L. Flear, 'The EU's biopolitical governance of advanced therapy medicinal products' (2009) 16 Maastricht J. of European and Comparative Law 113-37.

65 G.C. Bowker and S.L. Star, Sorting Things Out: Classification and its Consequences (2000). 
Classifying and formalizing practices shape new kinds of attachments that enrol persons in the performance of public practices such as medicine. ${ }^{66}$ One of the main avowed aims of the law building that we have described here is to achieve 'legal clarity' for human tissues and cells for therapeutic use and for regenerative technologies, and there is evidence of 'commensuration' processes $^{67}$ in the regulatory work of aligning different types of medical product with each other in the legislation discussed. Yet, in contrast, the high degree of complexity in distinctions between different materials, production processes, and institutional participants of regenerative medicine remains evident from our descriptions of the key legal provisions in the EU and two member states. The hybrid, transgressive characteristics of many investigational therapies and potential products is associated with a plethora of new legal regulations and exemptions from them. Classifications can usefully be seen as maps to the world of medical technologies. Indeed, in the United Kingdom at least, the production of 'roadmaps' by regulatory authorities is a distinctive feature of their communication with the world of regenerative medicine producers and researchers. Classifications emerge closely associated with the development of experimental scientific and clinical apparatuses as well as the production of scientific facts and institutional organization. One metaphor for this is of elements being 'mangled' together, adapted to the extreme diversity of biomedical contingencies. ${ }^{68}$

How do we explain the detailed progress of classification and subclassification of different materials and production and preparation processes constructing the 'material world' of regenerative medicine? Is it merely a question of the law progressively being evolved in attempts to respond to unstable, complex biologies and technologies, as we asked in our introduction? There are several answers to this question. First, from a legal point of view, given the peculiar federal nature of the EU polity, a main motive of classification comes from the principle of sharing competence between the EU and its member states. The EU can only regulate where it has competency, in this case, in cross-border movement of products (considered as goods in EU law and therefore submitted to the principle of free movement of goods) and where action at the EU level has added value in accordance with the subsidiarity principle applying in the field of public health. Member states may legislate individually on matters of national concern, such as, in the case considered here, products derived from human embryonic stem cells. This 'top-down' argument should be supplemented by a 'bottom-up' approach, that is, local forms of regulatory adjustments involving stakeholders at a national level. From a sociological point of view, one can

66 N. Marrres, 'The Issues Deserve More Credit: Pragmatist contributions to the study of public involvement in controversy' (2007) 37 Social Studies of Sci. 759-80.

67 W.N. Espeland and M.L. Stevens 'Commensuration as a social process' (1998) 24 Ann. Rev. of Sociology 313-43.

68 A. Pickering, The Mangle of Practice: Time, Agency and Science (1995). 
suggest that the "boundary work' ${ }^{69}$ of national implementation of EU laws amounts to a form of partial 'nationalization' of biomedical therapy and biomedical 'industry' - a phenomenon that has been called 'technonationalism'. ${ }^{70}$ This may be so, but from a legal perspective, the preferred interpretation would be that such boundary work is a national retention of competency by member states, which can of course result in varying priority being given to biomedicine. This boundary work of national implementation of EU law can also be seen as a bottom-up process that materializes in specific local spaces, which can be conceptualized as 'technological zones', ${ }^{71}$ characterized by the development of common standards and assessments of objects and practices, neither clearly bounded nor necessarily corresponding to the borders of nation-states.

Secondly, the agreed high level of risks for these biological products gives rise to a high degree of stringency which requires regulatory attention to procedures and products at a very high level of technical detailing. However, the 'stringency' that is being constructed here is ambiguous. On the one hand, we see a high degree of elaboration of EU legal frameworks and national provisions, providing for exceptions and adapting existing laws and principles. But on the other hand, it is notable that the ATMP product law in particular is open-ended on many matters concerning the technical assessment of yet-to-emerge products, justified on the grounds that these cannot be foreseen. Thus, issues of, for example, clinical data requirements for ATMPs are left outside society's (parliamentary) review process for 'comitology', that is, to the technical committees of the European Medicines Agency and its consultative processes. $^{72}$

Thirdly, and particularly for France as this discussion shows, the human materials character of these products highlights a distinctive classificatory organizing principle which has complex ramifications and is based on the strong attachment of French bioethics to respect for the autonomy and integrity of the human body and its elements, resting on upholding the ethical distinction between 'the thing and the person'. This derives from deep cultural and bioethical traditions, as well as being influenced by the well-known blood contamination scandals which reached the highest echelons of French government. Respect for the human body is expressed differently in the United Kingdom's implementation of the recent EU laws,

69 T.F. Gieryn, 'Boundary-work and the demarcation of science from non-science: strains and interests in professional ideologies of scientists' (1983) $48 \mathrm{Am}$. Sociological Rev. 781-95.

70 D. Edgerton, 'The Contradictions of Techno-Nationalism and Techno-Globalism: A Historical Perspective' (2007) 1 New Global Studies, at <http://www.bepress.com/ ngs/vol1/iss 1/art1>.

71 A. Barry, 'Technological Zones' (2006) 9 European J. of Social Theory 239-53; Faulkner, op. cit., n. 62.

72 A. Mahalatchimy et al., 'The European Medicines Agency: a public health European Agency?' (2012) J. of Medicine and Law (forthcoming). 
notably in the detailed exposition of the principle of informed consent in the Human Tissue Act, whose ramifications are materialized more in social procedures than in substantive person/property boundaries. Thus the two systems are markedly different in approach, though it remains arguable as to whether one is more or less 'stringent' compared to the other.

The legal developments described here position the EU and individual member states in the global world of regenerative medicine in which stakeholders compete and collaborate. ${ }^{73}$ In the still-evolving legal framework, we can see a mixture of measures designed to give commercial producers improved access to the European marketplace while protecting individualized biotherapies created in hospitals, and constructing stringent safety and risk management regulations for both. Having noted differences in the principles shaping the regulatory approaches of France and the United Kingdom, it is of interest to ask if there are differences between the two countries in the implications of the complex regulatory frameworks for biotherapy producers and users or patients in the respective healthcare systems. On the basis of this discussion, the implications appear similar in France and the United Kingdom. Indeed, the regulations across the differentiated categories of therapy are, in regulatory terms, deemed overall to enhance competitiveness for companies and foster innovation, at the same time providing, whether at EU or national level, very stringent requirements regarding the high level of safety risk. For users and patients, there are similar implications in the EU, and in France and the United Kingdom individually, for patients to access safe medicinal products. ${ }^{74}$ Although clear differences might emerge in the means and manner of reimbursement of products, that topic is beyond the scope of the present article.

What can we conclude about comparing the configuration of the different sets of regulatory institutions in each society, and how they 'match', or not, their corresponding, mobile regulatory objects and processes? These issues have been discussed in relation to other biomedical technologies. ${ }^{75}$ As noted, in France there is one primary national regulating agency for such products (either medical materials or health products including medicinal products) used for therapy, whereas in the United Kingdom three main national agencies are relevant. It could be argued that the French set-up matches the structure of the combined tissue and cells and advanced therapy framework more closely than the United Kingdom's, because the Regulation does not distinguish between different types of starting material, and this is also the case with the French national agency, although it does contain different

73 S. Saurugger, Théories et concepts de l'intégration européenne (2009).

74 A. Mahalatchimy, 'Access to advanced therapy medicinal products in the European Union: where do we stand?' (2011) 18 European J. of Health Law 305-17.

75 N. Brown et al., "Regulating Hybrids: "Making a Mess" and "Cleaning Up" in Tissue Engineering and Transpecies Transplantation' (2006) 4 Social Theory \& Health 1-24. 
pathways and product categories. Conversely, the differentiated agencies in the United Kingdom could also be seen as corresponding better to the two sets of complementary EU regulations (for tissues and cells, and for medicinal products) compared to the French agency. At the beginning of this article, we posed the question of whether regulatory institutional structures might 'naturally' reflect unstable biological and technical categorizations, or whether institutional structures were relatively 'free-floating'. Our analysis here, showing the wide national variation in structures implementing the same EU-level laws designed and adapted to cover the same field, supports the latter interpretation: regulatory institutional structures here have a high degree of flexibility in relation to the 'underlying' processes of material innovation, though they strain against existing, inherited legislations. Indeed, it would be more accurate to understand this not as 'implementation' but rather as a process of adaptation of EU laws, in which influence flows from EU to national jurisdictions and vice versa, and, in sociological terms, one of co-production between regulatory institutions and regulated 'objects'. 'Local' expectations, fears, and promises surrounding regenerative medicine's objects undoubtedly shape the institutional regulation of material innovation, possibly to a greater degree than the scientific data that accompany those objects. ${ }^{76}$ Governance activity has a constructive and shaping action as well as standardizing some material practices. The dynamics of the emerging medical world thus perform a complex web of codified legal narratives. ${ }^{77}$

This review necessarily leaves some loose ends. Although a legal framework has been created, some scientific and technological innovations escape its categories. At the same time, some aspects of the regulation at EU level are deliberately left loose, open to new technical developments. The two countries discussed here attempt to reconcile new rules with preexisting, institutionalized pharmaceutical and human tissue related principles - the 'inherited regulatory environment'. ${ }^{78}$ Perhaps most notable in terms of the materialization of law, in conclusion, is that alongside the elaborate construction of a new regulatory framework at EU level and its adaptation in national regimes, we also see that each new regenerative medicine product will have to receive a unique scientific expert assessment before being made available as a product in the healthcare system. It may be that the operation of discretion by committees of selected specialists considering innovations

76 N. Brown, 'Shifting Tenses - From Regimes of Truth to Regimes of Hope?' (2007) 13 Configurations 331-55.

77 A. Faulkner, How Law Makes Technoscience: The Shaping of Expectations, Actors and Accountabilities in Regenerative Medicine in Europe. (2010) CSSP Electronic Working Paper No.1, at <http://www.jnu.ac.in/Academics/Schools/ SchoolOfSocialSciences/CSSP/CSSP-EWPS-1.pdf>.

78 Compare E. Stokes, 'Nanotechnology and the Products of Inherited Regulation' in this volume, pp. 93-112. 
on a case-by-case basis will be the over-riding feature for deciding the regulatory route that new products and their developers will have to take. Experts' legitimacy here takes the form of institutional legitimacy via their formal affiliation to the European Medicines Agency as a mandated European Agency, and the technical legitimacy afforded by specific recognized skills. Thus, we conclude by pointing to the fact that, in spite of the regulatory reach of a complex and highly detailed new legal framework, a tailored case-by-case approach to deploying technical expertise nevertheless is required in regulating the fast-moving, innovative arena of regenerative medicine. 